\title{
Which Factors Affect the Hospital Re-admission After Treatment Approaches to Urethral Strictures?
}

\author{
Üretra Darlıklarında Tedavi Yaklaşımlarına Göre Hastaneye Tekrar Başvuruyu Etkileyen Faktörler
}

\author{
Reha Girgin \\ Bülent Ecevit University Faculty of Medicine, Department of Urology, Zonguldak, Turkiye
}

What's known on the subject? and What does the study add?

According to this study because re-admission to the hospital in younger patients with fewer comorbidities can be expected, it may be advisable to discharge this patient group after detailed examination.

\begin{abstract}
Objective: To investigate patient- and procedure-related factors associated with hospital re-admission following urethral manipulations for the treatment of urethral strictures.

Materials and Methods: Data of patients who underwent dilation or internal urethrotomy for urethral strictures between 2011 and 2016 were retrospectively analyzed. Patients who were admitted to our institute for any reason within one month after hospital discharge were evaluated. The patient- and procedure-related factors affecting the readmission rates were revealed by multiple binary logistic regression using stepwise backward elinimination.

Results: The average age of 76 male patients was $61.7 \pm 14.4$ years. The mean maximal flow rate at preoperative uroflowmetry was $6.01 \pm 4.3$ and the median American Society of Anesthesiologists score was 2.38. The process was the first for 45 (59.2\%) patients, the second for 16 (21.1\%) patients, the third for 9 (11.8\%) patients, and the fourth for 6 (7.9\%) patients. Amplatz dilators, cold knife and Ho:YAG laser were used in 50\%, 27.6\% and $22.4 \%$ of patients, respectively. The mean length of hospital stay was $0.89 \pm 0.31$ days, and the complication rate was $19.7 \%$ (15/76). The mean urethral catheter dwell time was $8.9 \pm 14.2$ day. Overall, the procedure was successful in $61(80.3 \%)$ patients and failed $\left(0_{\max }<15 \mathrm{~mL} / \mathrm{sec}\right)$ in $19.7 \%$ of the cases. Fifteen (19.7\%) patients were re-admitted, while $2(2.6 \%)$ patients among them were re-hospitalized for further treatment. Comorbidity and age were independent predictors of re-admission.
\end{abstract}

Conclusion: We found that younger age and lower comorbidities predicted hospital re-admission following procedures for urethral strictures.

Keywords: Urethral strictures, re-admission, risk factor

Öz

Amaç: Üretral darlıklara müdahale edildikten sonra hastaneye tekrar başvuru nedenleri ile ilişkili hasta ve prosedüre bağlı faktörleri araştırmaktır. Gereç ve Yöntem: 2011 ile 2016 yılları arasında üretra darlığı nedeni ile dilatasyon veya internal üretrotomi uygulanan hastaların tıbbi kayıtları retrospektif olarak incelendi. Hastaneden taburcu olduktan sonraki 30 gün içinde hastaneye herhangi bir sebeple yeniden başvuran hastalar değerlendirildi. Tekrar başvuru oranlarını etkileyen hasta ve prosedüre bağlı faktörler, geriye doğru kademeli çoklu ikili lojistik regresyon analizi kullanılarak ortaya çıkarıldı.

Bulgular: Yetmiş altı erkek hastanın yaş ortalaması $61,7 \pm 14,4$ yıldı. Preoperatif üroflowmetride ortalama maksimal akım hızı 6,01 $\pm 4,3$, ortalama Amerikan Anesteziyologları Derneği skoru 2,38 idi. Kırk beş $(\% 59,2)$ hastada birinci, $16(\% 21,1)$ hastada ikinci, $9(\% 11,8)$ hastada üçüncü, $6(\% 7,9)$ hastada dördüncü kez işlem yapıldı. Amplatz dilatörleri, soğuk bıçak ve Ho:YAG lazeri sırasıyla \%50, \%27,6 ve \%22,4 hastalarda kullanıldı. Ortalama

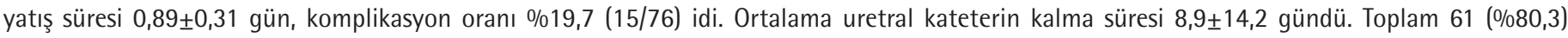
hastada başarı elde edildi. Olguların \%19,7'sinde işlem başarısız oldu $\left(0_{\text {maks }}<15 \mathrm{~mL} / \mathrm{sn}\right)$. On beş $(\% 19,7)$ hasta hastaneye tekrar başvurdu; 2 (\%2,6) hasta daha ileri tedavi için hastaneye yatırıldı. Komorbidite ve yaş, hastaneye tekrar başvurunun bağımsız öngörü faktörüdür.

Correspondence: Reha Girgin MD, Bülent Ecevit University Faculty of Medicine, Department of Urology, Zonguldak, Turkiye Phone: +90 5378865912 E-mail: mujdereha@hotmail.com ORCID ID: orcid.org/0000-0003-1132-8629

Received: 10.05.2017 Accepted: 08.08.2017

Cite this article as: Girgin R. Which Factors Affect the Hospital Re-admission After Treatment Approaches to Urethral Strictures? J Urol Surg 2017;4:171-176. 
Sonuç: Genç yaş ve düşük komorbiditenin üretra darlıkları için yapılan müdahaleler sonrasında hastaneye tekrar başvuruyu öngörebileceğini tespit ettik.

Anahtar Kelimeler: Üretral darlıklar, tekrar başvuru, risk faktörü

\section{Introduction}

It is necessary to learn more about the causes of hospital readmission following a pathology or an operation to improve the medical care of a patient and medical costs for such a case.

This study investigated the factors that are related to patient and procedure that increase the risk of hospital re-admission following urethral manipulations for the treatment of urethral strictures. As far as we know, this is the first study analyzing the factors affecting these rates.

\section{Materials and Methods}

After approval of the Ethics Committee (Institutional Review Board) of the Bülent Ecevit University Faculty of Medicine (date: 08/03/2017, meeting number: 2017/05, protocol number: $2017-$ 34-08/03), the medical records of patients who underwent dilation or internal urethrotomy for urethral strictures in our clinic from 2011 to 2016 were analyzed retrospectively. Patients, who were admitted to our institute for any reason related with the procedure within one month after hospital discharge, were evaluated. The written approval of all patients was obtained. The exclusion criteria were requirement of additional intervention e.g. transurethral prostate resection, transurethral bladder resection, treatment for more than one urethral stricture, any manipulation in the bladder, female gender, and age under 18 years. In this study, demographic data including patient age, American Society of Anesthesiologists (ASA) Physical Status Classification scores, Age-adjusted Charlson Comorbidity Index (ACCI) scores, type of anesthesia used, the location and length of the stricture, stricture etiology, preoperative uroflowmetry and parameters of the procedure, such as duration of the operation, method used in the surgery, the number of operation, properties of the urethral catheter used, length of hospital stay and urethral catheter withdrawal time were all evaluated. All patients were called for control at 1 month postoperatively and follow-up uroflowmetry was performed. If there were patients readmitted within the one month period until the first checkup, the duration, the reasons for re-admission and the type of treatment administered were all assessed.

\section{Surgical Procedure}

After giving a second-generation cephalosporin for prophylaxis, all patients were placed in the lithotomy position. With appropriate anesthesia, a standard cystourethroscopy (20 Fr,
Storz) was performed to exclude any urethral pathology. When a stricture was measured on a fluoroscopic image or seen on cystoscopy, a 0.035-inch safety wire was pushed forward to the bladder with the patient in the lithotomy position under fluoroscopic control (Figure 1a). Subsequently, a single 12 o'clock incision was made until the full thickness of the fibrous scar was divided with a standard Sachse urethrotomy knife with $21 \mathrm{Fr}$ urethrotome or Holmium laser probe (Stone Light, Mountain View, CA; Quanta System, Group, Italy) with cystoscope (20 Fr, Storz) (Figure 1b) or dilated more than $2 \mathrm{Fr}$ of the planned urethral catheter diameter with amplats dilators after coaxial placement via the guide and under fluoroscopy to minimize the traumatic process (Figure 1c). A complete success

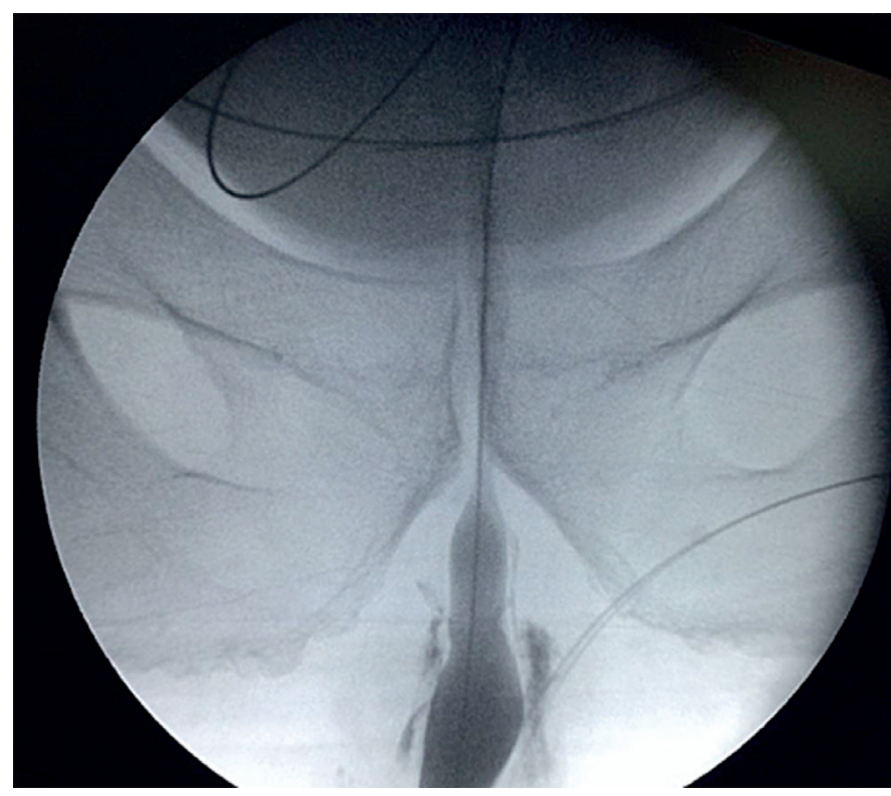

Figure 1a. Advanced guidewire to the bladder under fluoroscopic control

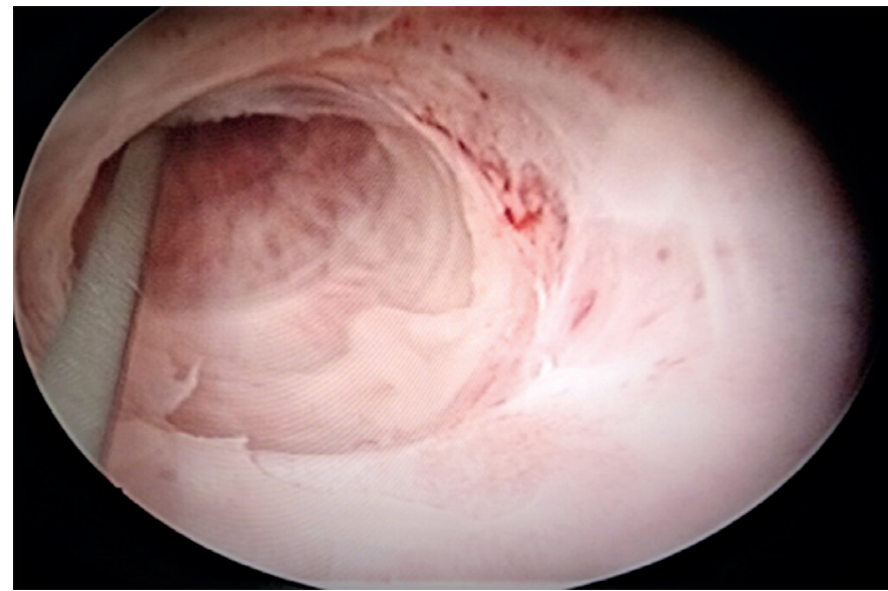

Figure $\mathbf{1 b}$. After incision with a standard urethrotomy knife or Holmium laser 
was considered once the $21 \mathrm{~F}$ urethrotome sheath or $20 \mathrm{Fr}$ cystoscope was freely inserted into the bladder. After the process a $16 \mathrm{Fr}$ or $18 \mathrm{Fr}$ silicone Foley catheter, occasionally, in recurrent strictures, a wider catheter existing in the operation room, was placed according to the decision of the physician. The patients were discharged with an indwelling catheter in the appropriate postoperative period. Oral second-generation cephalosporin was given until the catheter was removed. Urethral catheters remained in place for up to 90 days.

\section{Statistical Analysis}

This study was performed with SPSS 19.0. In the data set, descriptive statistics of the continuous variables were shown as mean and standard deviation and descriptive statistics of the categorical variables were shown as frequency and percent. The chi-square and Mann-Whitney $U$ tests were used for comparison of the categorical variables. The factors influencing the hospital re-admission rates were revealed by multiple binary logistic regression using stepwise backward elimination. A $p$ value of less than 0.05 was considered statistically significant.

\section{Results}

The average age of a total of 76 male patients included in the study was $61.7 \pm 14.4$ (range: $22-82$ ) years. The mean ACCI score was $4.2 \pm 2.6$ (range: $0-12$ ). The mean maximum flow rate at preoperative uroflowmetry was $6.01 \pm 4.3(0-14)$. The mean ASA score was 2.38. According to the ASA physical status classification, the patients were categorized as ASA $1(n=11$; $14.5 \%)$, ASA 2 ( $n=28 ; 36.8 \%)$, or ASA $3(n=34 ; 44.7 \%)$, or ASA $4(n=3 ; 3.9 \%)$. The process was the first for $45(59.2 \%)$ patients, the second for $16(21.1 \%)$ patients, the third for $9(11.8 \%)$ patients and the fourth for $6(7.9 \%)$ patients. The data about the strictures is given in Table 1.

Amplatz dilators were used in 38 (50\%) patients, cold knife in $21(27.6 \%)$ and holmium laser in 17 (22.4\%) patients. The mean

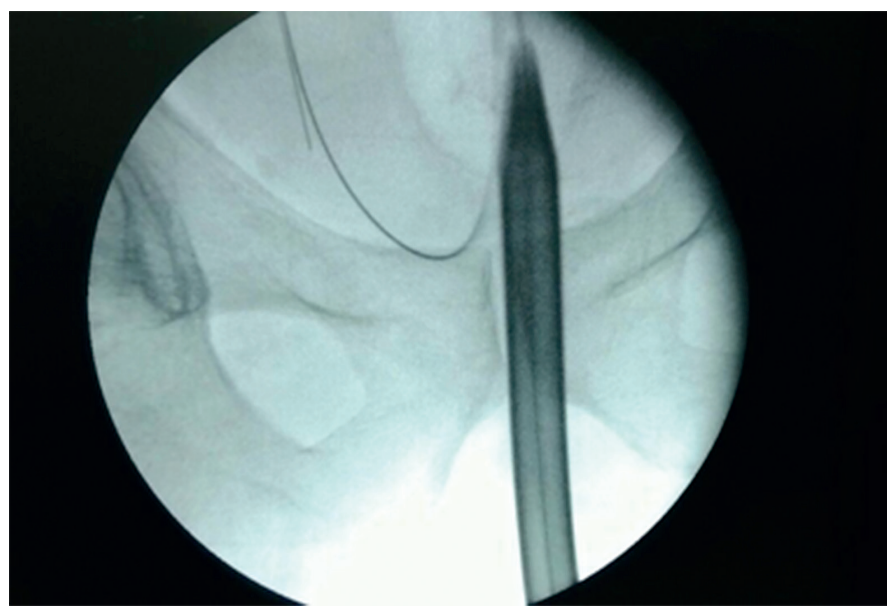

Figure 1c. Amplats dilation via the guidewire under fluoroscopy duration of the operation was $11.7 \pm 2.9$ (range: $7-21$ ) minutes. After the operation, in 57.9\% of patients, 16 Fr urethral catheter in 34.2\% - $18 \mathrm{Fr}$ urethral catheter, in 3.9\% - $20 \mathrm{Fr}$ urethral catheter and in 3.9\% of the patients, 22 Fr urethral catheter, all silicon in nature, were inserted.

The average length of hospital stay was $0.89 \pm 0.31$ (range: $0-1$ ) days, and the complication rate was $19.7 \%$ (15/76). The mean urethral catheter dwell time was $8.9 \pm 14.2$ days. Overall, the procedure was successful in $61(80.3 \%)$ patients. The procedure failed $\left(\mathrm{O}_{\max }<15 \mathrm{~mL} / \mathrm{sec}\right)$ in $19.7 \%$ of cases. After discharge from the hospital, among 15 (19.7\%) patients who were re-admitted, $2(13.3 \%)$ were re-hospitalized for further treatment. The most common causes for re-admission were urinary retention (46.6\%), incontinence (13.3\%), and tenesmus (13.3\%). One patient $(6.6 \%)$ with urinary retention and one patient $(6.6 \%)$ with pulmonary edema were hospitalized again. Overall, 1 (6.6\%) patient had grade 1 (hematuria), 6 (40\%) had grade 2 (epididimitis; $n=1$, incontinence; $n=2$, tenesmus; $n=2$, dysuria; $n=1), 6(40 \%)$ had grade 3a (urinary retention), 1 (6.6\%) had grade $3 b$ (urinary retention), and 1 (6.6\%) patient had grade 4 (pulmonary edema) complication according to the ClavienDindo classification of surgical complications (Table 2).

In Table 3, the therapies administered to overcome the causes of re-admission are summarized.

Table 1. The data about the stricure

\begin{tabular}{lll}
\hline Etiology of stricture & $\mathbf{n}$ & \% \\
\hline Primary & 6 & 7.9 \\
RRP & 12 & 15.8 \\
Cystourethroscopy & 7 & 9.2 \\
Urethral catheter insertion & 12 & 15.8 \\
Traffic accident & 4 & 5.3 \\
TUR-P & 22 & 28.9 \\
TUR-B & 12 & 15.8 \\
Urethroplasty & 1 & 1.3 \\
Stricture location & $\mathbf{n}$ & $\%$ \\
Bulbous & 17 & 22.4 \\
Memrenous urethra & 39 & 51.3 \\
Bladder neck & 8 & 10.5 \\
Penile urethra & 12 & 15.8 \\
Sricture length (mm) & $\mathbf{n}$ & $\%$ \\
5 & 3 & 3.9 \\
10 & 61 & 80.3 \\
20 & 10 & 13.2 \\
20< & 2 & 2.6 \\
\hline prostate, TUR-B: Transurethral resection of the bladder & & \\
\hline
\end{tabular}


Table 2. Common diagnoses at re-admission

\begin{tabular}{lll}
\hline Reason for re-admission & $\mathbf{n}$ & $\mathbf{\%}$ \\
\hline Pulmonary edema (contrast nephropathy) & 1 & 1.3 \\
Dysuria & 1 & 1.3 \\
Epididymitis & 1 & 1.3 \\
Difficulty in urination & 6 & 7.8 \\
Incontinence & 2 & 2.6 \\
Retention & 1 & 1.3 \\
Tenesmus & 2 & 2.6 \\
Ureterorrhagia & 1 & 1.3 \\
\hline
\end{tabular}

Table 3. The therapies applied to overcome the couses of re-admission

\begin{tabular}{lll}
\hline Applied therapy & $\mathbf{n}$ & $\%$ \\
\hline Amplatz dilatation & 1 & 1.3 \\
Medical & 7 & 9.2 \\
CIC dilatation & 5 & 6.6 \\
Follow-up & 1 & 1.3 \\
Internal urethrotomy & 1 & 1.3 \\
\hline CIC: Clean intermittent catheter & \multicolumn{3}{l}{} \\
\hline
\end{tabular}

Table 4. The association of re-admission rate with Ageadjusted Charlson Comorbidity Index scores and patients age

\begin{tabular}{lllll}
\hline \multicolumn{4}{c}{ Age } & \multicolumn{1}{c}{$\mathbf{p}$} \\
\hline Re-admission & $\mathbf{n}$ & Mean & (Min-Max) \\
No & 61 & $63.79 \pm 13.9$ & $22-82$ & $\mathbf{0 . 0 0 5}$ \\
Yes & 15 & $53.20 \pm 13.8$ & $28-80$ & \\
\multicolumn{5}{c}{ ACCl } \\
Re-admission & $\mathbf{n}$ & Mean & (Min-Max) \\
No & 61 & $4.68 \pm 2.5$ & $0-12$ & $\mathbf{0 . 0 0 7}$ \\
Yes & 15 & $2.66 \pm 2.2$ & $0-8$ & \\
\hline p<0.05: The level of significance & \\
ACCl: Age-adjusted Charlson Comorbidity Index, Min: Minimum, Max: Maximum \\
\hline
\end{tabular}

In univariate analysis, the re-admission rate was significantly associated with lower ACCI scores and patient age (Table 4, 5). In multivariate analysis, $\mathrm{ACCl}$ was an independent predictor of re-admission, while the other preoperative factors had not any predictive effect on re-admission.

\section{Discussion}

Male urethral strictures, a major challenge for urologists, are one of the urological diseases $(1,2)$. In parallel with the improvements in endoscopic procedures, treatment for urethral strictures has also improved. Cold knife incision, laser ablation or dilation methods can be used for stricture treatment. To make cold knife incision for urethral strictures, internal optical urethrotomy (IOU) was first introduced by Sachse (3) in 1974. IOU and urethral dilation together are generally considered to be the first choice for the treatment of most urethral strictures (2). Whichever method is preferred, a permanent urethral catheter in various sizes is inserted when the procedure is completed.
Table 5. The association of re-admission rate with sricture and operative data

\begin{tabular}{|c|c|c|c|}
\hline & Re-admissi & & $\mathbf{p}$ \\
\hline Stricture location & No & Yes & \\
\hline Bulbous & $14(23 \%)$ & $3(20 \%)$ & \\
\hline Memrenous urethra & $33(54 \%)$ & $6(40 \%)$ & 0.188 \\
\hline Bladder neck & $4(6.6 \%)$ & $4(26.7 \%)$ & \\
\hline Penile urethra & $10(16.4 \%)$ & $2(13.3 \%)$ & \\
\hline Sricture length (mm) & No & Yes & \\
\hline 5 & $3(4.9 \%)$ & $0(0 \%)$ & \\
\hline 10 & $49(80.3 \%)$ & $12(80 \%)$ & 0.591 \\
\hline 20 & $8(13.1 \%)$ & $2(13.3 \%)$ & \\
\hline $20<$ & $1(1.6 \%)$ & $1(6.7 \%)$ & \\
\hline Etiology of stricture & No & Yes & \\
\hline Primary & $3(4.9 \%)$ & $3(20.0 \%)$ & \\
\hline RRP & $8(13.1 \%)$ & $4(26.7 \%)$ & \\
\hline Cystourethroscopy & $5(8.2 \%)$ & $2(13.3 \%)$ & \\
\hline Urethral catheter insertion & $11(18 \%)$ & $1(6.7 \%)$ & 0.008 \\
\hline Traffic accident & $2(3.3 \%)$ & $2(13.3 \%)$ & \\
\hline TUR-P & $20(32.8 \%)$ & $2(13.3 \%)$ & \\
\hline TUR-B & $12(19.7 \%)$ & $0(0 \%)$ & \\
\hline Urethroplasty & $0(0 \%)$ & $1(6.7 \%)$ & \\
\hline Operation method & No & Yes & \\
\hline Dilatation & $30(49.2 \%)$ & $8(53.3 \%)$ & 1.000 \\
\hline Internal urethrotomy & $31(50.8 \%)$ & $7(46.7 \%)$ & \\
\hline Instrument used & No & Yes & \\
\hline Amplatz & $30(49.2 \%)$ & $8(53.3 \%)$ & \\
\hline Laser & $13(21.3 \%)$ & $4(26.7 \%)$ & 0.805 \\
\hline Cold knife & $18(29.5 \%)$ & $3(20.0 \%)$ & \\
\hline The number of processes & No & Yes & \\
\hline 1 & $36(59 \%)$ & $9(60 \%)$ & \\
\hline 2 & $13(21.3 \%)$ & $3(20 \%)$ & 1.000 \\
\hline 3 & $7(11.5 \%)$ & $2(13.3 \%)$ & \\
\hline 4 & $5(8.2 \%)$ & $1(6.7 \%)$ & \\
\hline Urethral catheter diameter (Fr) & No & Yes & \\
\hline 16 Fr silicon & $32(52.5 \%)$ & $12(80 \%)$ & \\
\hline 18 Fr silicon & $24(39.3 \%)$ & $2(13.3 \%)$ & 0.134 \\
\hline 20 Fr foley & $3(4.9 \%)$ & $0(0 \%)$ & \\
\hline 22 Fr silicon & $2(3.3 \%)$ & $1(6.7 \%)$ & \\
\hline Hospital stay (day) & No & Yes & \\
\hline 0 & $6(9.8 \%)$ & $2(13.3 \%)$ & 0.653 \\
\hline 1 & $55(90.2 \%)$ & $13(86.7 \%)$ & \\
\hline
\end{tabular}

The patient may be re-admitted after surgery due to various reasons. Many studies in the literature have investigated the reasons for re-admissions and the financial impact of readmissions $(4,5)$. The evaluation of these factors in the prediction and prevention of re-admissions can undoubtedly make a significant contribution. There are studies in the literature that review re-admissions after urolithiasis treatment and most have used national healthcare data instead of clinical or operative data $(4,6,7,8)$. 
Transurethral bladder tumor and prostate resection, transurethral laser prostatectomy, hydroentanglement, and suspension procedures were investigated by Rambachan et al. (5), and the median re-admission rates were found to be $4.97,4.24,4.27$, 1.92, and $0.85 \%$ (total median rate $3.7 \%$ ), respectively. Gender, patient age, anesthesia risk scores and history of malignancy and coagulation disorders were found to be risk factors for hospital re-admission. In this study, 30.9\% of re-admitted patients had medical complications and the commonest complication was urinary tract infection (20.6\%). Complications associated with surgical procedure were seen in $4.1 \%$ of patients, of which $21.3 \%$ had infection at the surgical field. Re-operation was required in $21.3 \%$ of re-admitted patients (5).

In a study by Scales et al. (4), re-admission rates after shock wave lithotripsy, ureterorenoscopy (URS), and percutaneous nephrolithotripsy (PCNL) were generally $12 \%$, but only $15 \%$ was after PCNL and URS. The re-admission rates rose in highvolume hospitals and were even higher in cases with a Charlson Comorbidity Index score of $\geq 2$ (4). In another study, unplanned hospital re-admission occurred in approximately one in every 10 patients, with elective re-admission rate of 13.6\%. In other studies, the rate of re-admission following stone treatment was around 5\% to 15\%. Readmitted patients had relatively longer initial hospital stays (8).

In this study, we investigated the related factors that increase the risk of re-admission in patients following IOU for urethral strictures. To our knowledge, this is the first such work. Similarly, this study included all post-operative re-admissions within 30 days after hospital discharge like studies of other procedures. The effects of factors such as preoperative comorbidities, operative data, length of hospital stay, and complications after operation were all revealed by this study. The average re-admission rate in our study was $19.7 \%$ which was a little higher than in the literature.

The role of etiology as the predictor of the outcome of IOU has long been investigated $(9,10)$. Kumar et al. (9) reported higher success rates with iatrogenic strictures when compared with posttraumatic and post-inflammatory etiology. However, Desmond et al. (10) could not find any association between the etiology of the stricture and the outcome of urethrotomy. In our study, although the re-admission rates due to the etiology of the stricture seems to be statistically significant, we could not make any conclusion about the relationship of the etiology of the stricture with re-admission rates and outcomes of the procedure.

Data on the effects of the diameter of the catheter placed after urethral stricture surgery are still insufficient. However, it is known that ischemia is involved in the process of recurrence of urethral stricture in most cases (11). Due to the pressure they exert on the urethral wall, larger diameter catheters may interfere with re-epithelialisation, which would result in urethral healing $(12,13)$. In a study of Yürük et al. (14), urethral stricture recurrence was found to be more common in patients with prolonged ( $\geq 5$ days) catheterization and with large $(22 \mathrm{Fr})$ catheters. Despite this information, according to our findings, we could not find any significant relationship of re-admission rates with the catheter diameter and catheter dwell time.

In a study, age was found to act as a prognostic factor that means patients younger than 13 and older than 60 years of age were found to be more exposed to postoperative complications. Odd ratio (OR) for this category was 3.4 (95\% confidence interval 1.86.6, $\mathrm{p}<0.001)$; thus, the probability to suffer a complication during postoperative period was nearly 3.5 times higher for patients under 13 and over 60 years compared with patients aged between 13 and 59 years (15). In our study, age and $\mathrm{ACCl}$ were found to be a factor related with re-admission. In multivariate analysis, $\mathrm{OR}$ for $\mathrm{ACCl}$ was 0.69 which means that an increase in the score of $\mathrm{ACCl}$ reduces the re-admission rate nearly by $50 \%$.

Ambulatory urological surgery is highly safe when evaluated for postoperative complications. Surgical procedures performed under general anesthesia, except for factors that cannot be changed, such as age, sex, surgical type, and the complexity of surgery, are independent risk factors for complications after operation and re-admission (15). Similarly, complicated procedures increase the risk of complications (15). In our study, an increase in preoperative comorbidities decreases the rate of hospital re-admission; likewise older age also reduces the hospital re-admission rate. We think that this may be related to the operator being more careful in the elderly and comorbid patient groups.

\section{Study Limitations}

This study has some weaknesses: the accuracy of our analysis may be debatable because of its retrospective nature. Furthermore, since the data on outpatient visits are limited, postoperative complications may be underestimated. Other limitations are small sample sizes for urethral stricture surgery. In addition, a large number of different data have been classified so that a detailed analysis of the process has become impossible. In the current conditions, with larger series of patients, it is likely to make further comments.

\section{Conclusion}

Operation for urethral stricture, which is among the ambulatory urological surgical procedures, is generally a safe procedure, but it may cause more irritation to a patient group that will be readmitted to the hospital. When the cost is taken into account, identification of this group of patients is important. According to this study, because hospital re-admission in younger patients 
with fewer comorbidities can be expected, it may be advisable to discharge, this patient group after detailed examination.

\section{Ethics}

Ethics Committee Approval: The study was approved by Bülent Ecevit University Local Ethics Committee (date: 08/03/2017, meeting number: 2017/05, protocol number: 2017-34-08/03).

Informed Consent: Consent form was filled out by all participants.

Peer-review: Externally peer-reviewed.

Financial Disclosure: The author declared that this study received no financial support.

\section{References}

1. Wong SS, Aboumarzouk OM, Narahari R, O'Riordan A, Pickard R. Simple urethral dilatation, endoscopic urethrotomy, and urethroplasty for urethral stricture disease in adult men. Cochrane Database Syst Rev 2012;12:CD006934.

2. Buckley JC, Heyns C, Gilling P, Carney J. SIU/ICUD Consultation on Urethral Strictures: Dilation, internal urethrotomy, and stenting of male anterior urethral strictures. Urology 2014;83(Suppl):S18-22.

3. Sachse H. Treatment of urethral stricture: Transurethral slit in view using sharp section. Fortschr Med 1974;92:12-15.

4. Scales CD Jr, Saigal CS, Hanley JM, Dick AW, Setodji CM, Litwin MS; NIDDK Urologic Diseases in America Project. The impact of unplanned postprocedure visits in the management of patients with urinary stones. Surgery 2014;155:769-775.

5. Rambachan A, Matulewicz RS, Pilecki M, Kim JY, Kundu SD. Predictors of readmission following outpatient urological surgery. J Urol 2014;192:183-188.

6. Sfoungaristos S, Hidas G, Gofrit ON, Rosenberg S, Yutkin V, Landau EH, Pode
D, Duvdevani M. A novel model to predict the risk of readmission in patients with renal colic. J Endourol 2014;28:1011-1015.

7. Fwu CW, Eggers PW, Kimmel PL, Kusek JW, Kirkali Z. Emergency department visits, use of imaging, and drugs for urolithiasis have increased in the United States. Kidney Int 2013;83:479-486.

8. Armitage JN, Withington J, van der Meulen J, Cromwell DA, Glass J, Finch WG, Irving SO, Burgess NA. Percutaneous nephrolithotomy in England: practice and outcomes described in the Hospital Episode Statistics database. BJU Int 2014;113:777-782.

9. Kumar S, Kapoor A, Ganesamoni R, Nanjappa B, Sharma V, Mete UK. Efficacy of holmium laser urethrotomy in combination with intralesional triamcinolone in the treatment of anterior urethral stricture. Korean J Urol 2012;53:614-618

10. Desmond AD, Evans CM, Jameson RM, Woolfenden KA, Gibbon NO. Critical evaluation of direct vision urethrotomy by urine flow measurement. $\mathrm{Br} J$ Urol 1981;53:630-633.

11. Tian $Y$, Wazir $R$, Yue $X$, Wang KJ, Li H. Prevention of stricture recurrence following urethral endoscopic management: what do we have? J Endourol 2014;28:502-508.

12. Liss, MA, Skarecky D, Morales B, Osann K, Eichel L, Ahlering TE. Preventing perioperative complications of robotic-assisted radical prostatectomy. Urology 2013;81:319-323.

13. Karakus SC, Koku N, Parmaksiz ME, Ertaskin I, Kilincaslan H, Deliaga H. The effect of urethral catheter size on meatal stenosis formation in children undergoing tubularized incised plate urethroplasty. J Urol 2014;10:10951098.

14. Yürük E, Yentur S, Çakır ÖO, Ertaş K, Şerefoğlu EC, Semerciöz A. Catheter dwell time and diameter affect the recurrence rates after internal urethrotomy. Turk J Urol 2016;42:184-189.

15. Paez A, Redondo E, Linares A, Rios E, Vallejo J, Sanchez-Castilla M. Adverse Events and Readmissions after Day-Case Urological Surgery. Int Braz J Urol 2007;33:330-338. 